\title{
Orientations in learning English as a foreign language: How do Indonesian students view them?
}

\author{
Kaspul Anwar ${ }^{*}$, M. Faruq Ubaidillah ${ }^{2}$, Veronico N. Tarrayo ${ }^{3}$, \\ Febti Ismiatun ${ }^{4}$, Khusnul Khotimah ${ }^{5}$, Irawansyah 6 , and Urip Sulistiyo7 \\ ${ }^{1}$ English Education Department, STAI Ahsanta Jambi/Center for Scientific Publication, \\ Universitas Jambi, Indonesia \\ ${ }^{2}$ Center for Scientific Publication, Universitas Negeri Malang/Graduate Program in ELT, \\ Universitas Islam Malang, Indonesia \\ ${ }^{3}$ Department of English University of Santo Tomas, Manila, Philippines \\ ${ }^{4}$ English Education Department, Universitas Islam Malang, Indonesia \\ 5English Education Department, Universitas Mataram, Indonesia \\ ${ }^{6}$ English Education Department, UIN Raden Intan, Indonesia \\ 7 English Education Department, Faculty of Teacher Training and Education Universitas \\ Jambi, Indonesia \\ *Corresponding author \\ Email: kaspulanwar.as@gmail.com
}

\begin{abstract}
Anchored by the scant studies on Indonesian junior high school students' orientation in learning English as a foreign language, this present study showcased how their learning orientation, delved into integrative and instrumental orientation models, was enacted. 144 students were recruited to answer an integrative and instrumental orientation 20-item questionnaire adapted from Attitude Motivation Test Battery (AMTB). Findings suggested that in terms of integrative orientation, the participants viewed learning English as a gateway to knowing and understanding native speakers' cultural norms. This tenet was echoed by the global spread of English. In terms of instrumental orientation, the participants believed that learning English assisted them in career advancement. The results of this study concluded that the students, despite positively favored in learning English, leaned their English learning orientation on the native speakerism issue and the global spread of English.
\end{abstract}

Keywords: Attitude Motivation Test Battery (AMTB); English as a Foreign Language (EFL); Integrative Orientation; Instrumental Orientation

Received: Revised: Accepted: Published:

21 November $2019 \quad 11$ February $2020 \quad 14$ February $2020 \quad 29$ February 2020

\section{INTRODUCTION}

In recent years, scholars have witnessed the significance of motivation in language learning (Anwar \& Nugroho, 2018; Anwar, 2018; Gardner, 2005; Jiang, 2014; Kitjaroonchai \& Kitjaroonchai, 2012; Long et al., 2013; Muray et al., 2011; Sepora et al., 2012). For instance, a study carried out by (Dörnyei, 2001) informed that motivation as one of the critical factors to sustained language learning. Many conceptualizations of motivation in language learning 
literature have been geared. One of which is the socio-educational model on second language motivation (Gardner, 1975, 2005, 2012). According to this model, motivation is conceptualized as a complex variable. Precisely, Gardner put it, "the combination of effort plus desire to achieve the goal of learning the language plus favorable attitudes towards learning the language" (Gardner, 1985 , p. 10). Motivation in this theory is supported by two components, namely integrative and instrumental orientations. Dörnyei (1998) contended that the dichotomy of integrative orientation and instrumental orientation in Gardner's socio-educational theory leads to orientation (goal) for learning. Besides, Dörnyei (2001) argued that the role of orientation is to raise motivation and direct it towards a set of goals, either with a stable interpersonal quality (integrative orientation) or a robust, practical quality (instrumental orientation).

Gardner et al. (1985) viewed integrative orientation towards learning the language, favorable attitudes towards the language community, and general openness towards another group in general or sometimes interpreted as an interest in foreign languages. In other words, Gardner (1985) defined integrative as a desire to be a representative member of the other language community. Moreover, Lamb (2012) asserted that the notion of integrative orientation is a desire to learn a language in order to come closer to the other language community. Meanwhile, instrumental orientation has been defined as the "desire to gain social recognition or economic advantages through knowledge of a foreign language," e.g., finding a job, being promoted, satisfying an academic requirement (Masgoret \& Gardner, 2003, p. 125). Lamb (2012) pointed out that the theoretical justification for this view lies in the fact that learning another language is not like learning math. It is likely to involve not only the linguistic and cognitive capacities but also the social, historical, emotional, cultural, and moral sense of the self as a subject.

According to Atay \& Kurt (2010), Gardner's socio-educational orientation captures a tendency of having concerns for international affairs and a readiness to interact with people other than those in one's community. Furthermore, many researchers have explored the significance of motivation using Gardner's socio-educational orientation model (Ahmadi, 2011; Atay \& Kurt, 2010; Ghanbarpour, 2014; Hashemi \& Hadavi, 2014). However, it is surprising that this issue is neglected in the Indonesian context. Therefore, the present work attempted to fill the gap by studying the socio-educational orientation in the Indonesian context and investigated the orientations of Indonesian students for learning English. This study puts a focus on the students' integrative and instrumental orientation. In the present study, the researchers employed the AMTB integrative and instrumental orientations scales format of (Clément et al., 1994; Kitjaroonchai, 2013; Liu, 2007; Wang, 2008) to expand and test it in an EFL setting in Indonesian secondary schools.

\section{Integrative and Instrumental Orientation in EFL contexts}

The development of the socio-educational model of second language acquisition has resulted in numerous research on EFL studies. Specifically, two different views have been reported in the literature on the relationship between integrative and instrumental orientation. For instance, Yu \& Downing (2012) examined the effects of integrative motivation and instrumental 
motivation and second language proficiency in China using AMTB. The study suggested that integrative motivation encompasses a more critical role in predicting students' socio-cultural adaptation. Likewise, the integrative orientation of the learners might sustain a longer desire and interest in identifying the people of the host country, which is likely to contribute to better socio-cultural adaptation in the long run.

Moreover, the relationship between motivation and language proficiency has been investigated. Samad et al. (2012) revealed that there was no significant positive correlation coefficient between instrumental orientation and students' proficiency in learning a foreign language $(r=0.35)$. However, the study found that there was a significant positive relationship between integrative motivation and students' proficiency in learning EFL ( $\mathrm{r}=0.72)$. A study from the perspective of Koreans' learners was enacted (Ooyoung Pyun, 2013). This study uncovered that students' attitudes were positively associated with anxiety. Moreover, from the multiple regression analysis, the study found that integrative motivation was positively correlated with students' attitudes and was became essential for success in L2 and EFL learning.

Another study was carried out by (Ghanbarpour, 2014) on the willingness to communicate in the Iranian EFL context using Gardner's socioeducational model. He observed that integrative and instrumental orientation became a significant determinant of learners' success in L2 learning procedures. However, in this study, it was found that the instrumental orientation significantly contributed to the willingness to communicate in English. Moreover, in the level of secondary and high schools, Kitjaroonchai (2013) in Thailand investigated the English learning motivation of 266 secondary and high school students in Saburi, Thailand and revealed that instrumental orientation was slightly outperformed under the students' integrative orientation.

A review of the studies above may inform how instrumental motivation and integrative orientation in learning English have been researched for years. However, in the Indonesian context, this issue is under-explored. Indonesia encompasses rural areas that facilitate English learning for students in secondary schooling sectors. It is, thereby, sheds significant insights to look at how the students enact the instrumental and integrative orientation in English learning.

\section{METHOD}

This survey study recruited 144 Indonesian junior high school students based in Jambi city, Indonesia. They were selected randomly. Theoretically, the reason for involving junior high school students was because, at this level, they have a curiosity and willingness to learn a foreign language. Particularly, the students beginto think critically and focus on themselves and how they perceived by their peers (Pennington, 2009). The demographic profile also is known that 19 participants (13.2\%) live in a remote area, while 125 live in urban areas. To ensure anonymity, all the names of the participants were pseudonyms Besides, before doing this research, the researchers have received permission from the Indonesian National Unity and Political Agency (Kesbangpol), Jambi Province, Indonesia. 
To obtain the data, a set of questionnaire was utilized in this study. The questionnaire involves twenty items, which consist of ten questions for integrative orientation and ten questions for instrumental orientation. This questionnaire was an adapted version of Gardner's Attitudes Motivational Test Battery (AMTB) using integrative and instrumental orientations scales format of (Clément et al., 1994; Kitjaroonchai, 2013; Liu, 2007; Wang, 2008). Each item was scored based on the Likert scale (score 1 for 'strongly disagree' to 5 'strongly agree'). For this study, the questionnaire was translated into the students' national language. It was done to enable them to construe the meaning of the questions effectively. Furthermore, prior to distributing the questionnaire, a tryout and validity examination were enacted. The result of Cronbach's Alpha test showed that the reliability value of the questionnaire was 0.856. This implies that the questionnaire was valid and reliable to be used in this study.

To analyze the data, SPSS 23.0 program was utilized. From the data, the demographic profile of the participants in this study consisted of 67 males $(46.5 \%)$ and 77 females $(53.5 \%)$. The data in this study were fed into the computer and then was analyzed by using SPSS 23.0 program. The participants were asked to indicate five points Likert scale to show their reason for learning English as a foreign language. The focus was on two types of motivational orientation, integrative and instrumental following adapted version of Gardner's Attitudes Motivational Test Battery (AMTB) using integrative and instrumental orientations scales format of (Clément et al., 1994; Kitjaroonchai, 2013; Liu, 2007; Wang, 2008). Twenty statements were designed to find out the principal reason for learning English as a foreign language.

\section{RESULTS AND DISCUSSION Students' integrative learning orientation}

Table 2. Integrative orientation (frequency distribution and mean score)

\begin{tabular}{|c|c|c|c|c|c|c|c|c|c|c|}
\hline \multirow[t]{2}{*}{$\begin{array}{c}\text { Numb } \\
\text { er }\end{array}$} & \multicolumn{2}{|c|}{$\begin{array}{c}\text { 1. To } \\
\text { understand } \\
\text { native } \\
\text { culture and } \\
\text { tradition }\end{array}$} & \multicolumn{2}{|c|}{$\begin{array}{l}\text { 2. To } \\
\text { understand } \\
\text { English } \\
\text { stories }\end{array}$} & \multicolumn{2}{|c|}{$\begin{array}{l}\text { 3. To } \\
\text { participate in } \\
\text { native } \\
\text { speaker } \\
\text { group }\end{array}$} & \multicolumn{2}{|c|}{$\begin{array}{l}\text { 4. To } \\
\text { understand } \\
\text { the ways of } \\
\text { life native } \\
\text { speakers }\end{array}$} & \multicolumn{2}{|c|}{$\begin{array}{l}\text { 5. To make } \\
\text { friends with } \\
\text { foreigners }\end{array}$} \\
\hline & Freq. & $\%$ & Freq. & $\%$ & Freq. & $\%$ & Freq. & $\%$ & Freq. & $\%$ \\
\hline 1 & & & 2 & 1.4 & 1 & 0.7 & 2 & 1.4 & 4 & 2.8 \\
\hline 2 & 4 & 2.8 & 4 & 2.8 & 6 & 4.2 & $\overline{1}$ & 0.7 & 5 & 3.5 \\
\hline 3 & 17 & 11.8 & 18 & 12.5 & 19 & 13.2 & 35 & 24.3 & 26 & 18.1 \\
\hline 4 & 60 & 41.7 & 52 & 36.1 & 64 & 44.4 & 63 & 43.8 & 47 & 32.6 \\
\hline 5 & 63 & 43.8 & 68 & 47.2 & 54 & 37.5 & 43 & 29.9 & 62 & 43.1 \\
\hline Total & 4.26 & & 4.25 & & 4.14 & & 4.00 & & 4.10 & \\
\hline \multicolumn{11}{|l|}{ mean } \\
\hline \multirow[t]{2}{*}{$\begin{array}{c}\text { Numb } \\
\text { er }\end{array}$} & \multicolumn{2}{|c|}{$\begin{array}{l}\text { 6. To associate } \\
\text { and learn } \\
\text { native values } \\
\text { and beliefs }\end{array}$} & \multicolumn{2}{|c|}{$\begin{array}{c}\text { 7. Behaves like } \\
\text { American } \\
\text { and British }\end{array}$} & \multicolumn{2}{|c|}{$\begin{array}{l}\text { 8. Believe } \\
\text { American } \\
\text { and British } \\
\text { are kind and } \\
\text { cheerful }\end{array}$} & \multicolumn{2}{|c|}{$\begin{array}{l}\text { 9. To enjoy } \\
\text { English } \\
\text { movies }\end{array}$} & \multicolumn{2}{|c|}{$\begin{array}{l}\text { To enjoy } \\
\text { reading } \\
\text { English } \\
\text { books }\end{array}$} \\
\hline & Freq. & $\%$ & Freq. & $\%$ & Freq. & $\%$ & Freq. & $\%$ & Freq. & $\%$ \\
\hline 6 & & & 1 & 0.7 & & & 1 & 0.7 & 4 & 2.8 \\
\hline 7 & 5 & 3.5 & 10 & 6.9 & 14 & 9.7 & 15 & 10.4 & 18 & 12.5 \\
\hline
\end{tabular}




\begin{tabular}{|c|c|c|c|c|c|c|c|c|c|c|}
\hline 8 & 28 & 19.4 & 30 & 20.8 & 62 & 43.1 & 50 & 34.7 & 60 & 41.7 \\
\hline 9 & 61 & 42.4 & 63 & 43.8 & 49 & 34.0 & 53 & 36.8 & 47 & 32.6 \\
\hline 10 & 50 & 34.7 & 40 & 27.8 & 19 & 13.2 & 25 & 17.4 & 15 & 10.4 \\
\hline Total & 4.08 & & 3.91 & & 3.51 & & 3.60 & & 3.35 & \\
\hline \multirow{2}{*}{\multicolumn{11}{|c|}{ mean }} \\
\hline & & & & Ove & & .92 & & & & \\
\hline
\end{tabular}

Table 2 documented the student inclination towards integrative orientation. The data found that most of the students agreed that studying English is essential (item 1-3). For instance, most of them answered 'agree' and 'strongly agree,' arguing that they learn English as a foreign language to understand native' culture and tradition (85.4\%). Findings of this integrative orientation corroborate previous studies discerning prominently held belief of native speaker fallacy in Asia (Glasgow, 2018; Hashimoto, 2018; Heimlich, 2018; Kunschak, 2018; Yano, 2020). In particular, this fallacy is held much in English as a foreign language teaching and learning, putting native speakers as ideal models for learning English (Ubaidillah, 2018a).

Furthermore, it was unveiled that two essential points related to the students' integrative orientation in learning English. First, the majority of them agreed that learning English is vital to understand cultures, traditions, literature, and interacting with native speakers. Second, they also believed that when they enjoy learning English, it would be easier for them to communicate with foreigners or native speakers. Overall, the present findings are consistent with the recent discussions, which pointed out that, ideology and identity construction in the English language is influenced by this a political discourse shaped within this language per se (Fang, 2018; Edwards, 2016; Muray et al., 2011; Qu, 2011). According to Muftah \& Rafic-Galea (2013), learners have their reasons why they integrate themselves into a target language community, which involves knowing the native speakers' culture, beliefs, and so forth.

\section{Students' instrumental learning orientation}

Table 3. Instrumental orientation

\begin{tabular}{|c|c|c|c|c|c|c|c|c|c|c|}
\hline \multirow[t]{2}{*}{$\begin{array}{c}\text { Numb } \\
\text { er }\end{array}$} & \multicolumn{2}{|c|}{$\begin{array}{l}\text { 1. To get an } \\
\text { ideal job }\end{array}$} & \multicolumn{2}{|c|}{$\begin{array}{l}\text { 2. For future } \\
\text { career }\end{array}$} & \multicolumn{2}{|c|}{$\begin{array}{c}\text { 3. To become } \\
\text { knowledgeab } \\
\text { le }\end{array}$} & \multicolumn{2}{|c|}{$\begin{array}{l}\text { 4. To get } \\
\text { respect from } \\
\text { other }\end{array}$} & \multicolumn{2}{|c|}{$\begin{array}{c}\text { 5. For further } \\
\text { studies }\end{array}$} \\
\hline & Freq. & $\%$ & Freq. & $\%$ & Freq. & $\%$ & Freq. & $\%$ & Freq. & $\%$ \\
\hline 1 & 3 & 2.1 & & & & & 4 & 2.8 & 2 & 1.4 \\
\hline 2 & 3 & 2.1 & 1 & 0.7 & 1 & 0.7 & 13 & 9.0 & 3 & 2.1 \\
\hline 3 & 24 & 16.7 & 16 & 11.1 & 17 & 11.8 & 51 & 35.4 & 11 & 7.6 \\
\hline 4 & 54 & 37.5 & 59 & 41.0 & 56 & 38.9 & 53 & 36.8 & 55 & 38.2 \\
\hline 5 & 60 & 41.7 & 68 & 47.2 & 70 & 48.6 & 23 & 16.0 & 73 & 50.7 \\
\hline Total & 144 & 100 & 144 & 100 & 144 & 100 & 144 & 100 & 144 & 100 \\
\hline mean & 4.15 & & 4.34 & & 4.35 & & 3.54 & & 4.35 & \\
\hline
\end{tabular}

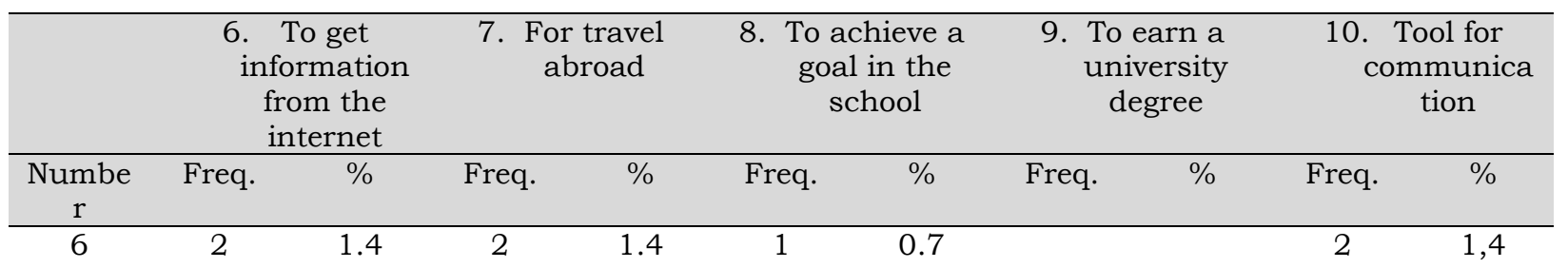




\begin{tabular}{ccccccccccc}
7 & 4 & 2.8 & 3 & 2.1 & 5 & 3.5 & 2 & 1.4 & 8 & 5,6 \\
8 & 21 & 14.6 & 30 & 20.8 & 29 & 20.1 & 35 & 24.3 & 26 & 18,1 \\
9 & 67 & 46.5 & 51 & 35.4 & 64 & 44.4 & 51 & 35.4 & 51 & 35,4 \\
10 & 50 & 34.7 & 58 & 40.3 & 45 & 31.3 & 56 & 38.9 & 57 & 39,6 \\
\hline Total & 144 & 100 & 144 & 100 & 144 & 100 & 144 & 100 & 144 & 100 \\
\hline mean & 4.10 & & 4.11 & \multicolumn{9}{c}{ Overall Mean= 4.11 } \\
\hline \multicolumn{10}{r}{} \\
\hline
\end{tabular}

Table 3 portrayed student responses toward instrumental orientation. The results suggested that $79 \%$ of the students responded 'agree' and 'strongly agree', believing that mastering English would help them to get an ideal job. Then, $88 \%$ of them agree that learning English is important for their future careers. Besides, $87.5 \%$ agree that mastering English can improve their understanding and become knowledgeable. Likewise, 76 out of 144 participants agreed that learning English would make them respected by others.

Furthermore, more than $8.25 \%$ of the students agreed that English could help them to access the internet and get information. Additionally, the importance of English in higher education was believed by the majority of the students $(88.8 \%)$, contending that English could help them to get a better education in the future. It is evident from their choices such as to earn a university degree (74.5\%) and achieve their goals at school (75.6\%). They also admitted that English is an essential tool for international communication (75\%), e.g., to travel abroad (75.7\%).

This study unveiled that the three highest-scoring questions are studying English for a future career (4.34\%), to become knowledgeable (4.35\%), and for higher education (4.35\%). The result of this study corroborates a study from (Rahman, 2005) who reported that the desire to learn English for higher education and get a better job is a natural side of instrumental orientation. The data also emphasize a study from (Ghanbarpour, 2014) who reported that an individual's purpose of learning English to find a job, being promoted, satisfying an academic requirement, or other similar issues, persuaded by instrumental motivation. Additionally, the finding of this study also confirms a study from (Masgoret \& Gardner, 2003), who suggested that instrumental orientation as a desire to gain social recognition or economic benefits.

From this study, it was found that integrative and instrumental orientations are echoed as students' motivation in learning English. Furthermore, based on the analysis, two essential points related to the students' integrative orientation in learning English was uncovered. First, the majority of the respondents agreed that learning English is vital to understand cultures, traditions, literature, and interacting with native speakers. Second, the respondents believed that when they enjoy learning English, it would be easier for them to communicate with foreigners or native speakers. Overall, the present findings are consistent with the recent discussion, which points to the notion that when people enjoy language learning, they will view "language learning as a puzzle that has few repercussions in everyday life" (Noels et al., 2003). According to (Muftah \& Rafic-Galea, 2013), learners have their reasons why they integrate themselves into a target language community, which involves knowing the native speakers' culture, beliefs, and the like Muftah \& 
Rafic-Galea (2013) also added that learning a target language does not negatively affect a learner's own culture or language.

Interestingly, students' instrumental orientation is central to their career advancement assisted by English proficiency. Such an orientation of the importance of English as an international language can help the students prepare themselves to meet the essential global standards for using the target language, which may focus more on practical communication skills such as planning how to communicate with native speakers and interact with other people when traveling abroad. Samad et al. (2012), for instance, suggested that educational institutions should focus on these skills and knowledge in the field of EFL by adhering to English as a lingua franca communication (Yano, 2020). Hence, learners, in terms of instrumental orientation, have different reasons for learning English as a second or a foreign language, e.g., to get into a university, to fulfill a university language requirement, or to get a salary raise. Additionally, Noels et al. (2010) concluded that learning a language because of integrative or instrumental orientation does not always expect learners' effort or determination, that is, "as long as the reward or punishment is insight, the subject may involve in learning; once it is removed, however, engagement will likely terminate" (p. 432).

In summary, the present study aimed to investigate students' integrative and instrumental orientation for learning English as a foreign language in the Indonesian context. The data from the survey demonstrated a similarity between integrative and instrumental orientations, which, to the best of our scholarly understanding, pertain to favor native speaker fallacy (Ubaidillah, 2018b). The present study also shares a realistic picture that instrumental and integrative orientations in learning English are projected to future career development, opportunities to go abroad, success in further studies, and skills to interact with peoples from different cultures and circumstances (Muftah \& Rafic-Galea, 2013). Thereby, English language teachers, in their effort to encourage students to learn English, need to develop an ELF-aware pedagogy in their classroom, so the students are well-equipped for intercultural communication (Bayyurt \& Sifakis, 2015).

\section{CONCLUSION}

This study attempted to uncover how students' integrative and instrumental orientations in learning English were enacted. Findings have informed that, despite their favor in learning the language, beliefs of native speaker attributes as the target learning is held. This implies that English teachers, particularly in the Indonesian context, are required to develop ELF-aware pedagogy in educational sectors so that students are ready for lingua franca communications in advancing their careers. This study is open to several limitations. First, since participants involved in this study were limited, the generalization would not be possible. Thus, future works are encouraged to survey more participants in different regions around Indonesia. Besides, indepth interviews are also crucial since individuals' stories through interviews lead to an identity voice, which, assuredly, signals their true feelings (Maxwell, 2013). 


\section{ACKNOWLEDGMENTS}

This study would not have been possible without the involvement of the participants and consent from the Indonesian National Unity and Political Agency (Kesbangpol), Jambi Province, Indonesia. The authors also address special thanks to the anonymous reviewers of EduLite Journal for their insightful comments on the earlier version of this paper.

\section{REFERENCES}

Ahmadi, M. R. (2011). The effect of integrative and instrumental motivation on Iranian EFL Learners ' Language Learning. ELT Voices, April, 7-16.

Anwar, C., \& Nugroho, K. Y. (2018). Students' motivation towards choosing English education. Indonesian EFL Journal, 4(1), 57-64. https://doi.org/10.25134/ieflj.v4i1.799.

Anwar, K. (2018). The students' motivation and teachers' problems in teaching English at junior high school. Jambi University.

Atay, D., \& Kurt, G. (2010). The socio-educational model of second language acquisition: The Turkish context. Procedia - Social and Behavioral Sciences, 2(2),

3088-3093. https://doi.org/10.1016/j.sbspro.2010.03.470

Bayyurt, Y., \& Sifakis, N. C. (2015). ELF-Aware In-Service Teacher Education: A transformative perspective. in $\mathrm{H}$. Bowles \& A. Cogo (Ed.), International Perspectives on English as a Lingua Franca (pp. 117-135). Palgrave Macmillan UK. https://doi.org/10.1057/9781137398093_7

Clément, R., Dornyei, Z., \& Noels, K. A. (1994). Motivation, self confidence, and group cohesion in the foreign language classroom. Language Learning, 44, 417-448. $\quad$ https://doi.org/10.1111/j.14671770.1994.tb01113.x

Dörnyei, Z. (1998). Motivation in second and foreign language learning. Language Teaching, 31(3), 117-135. https://doi.org/10.1017/S026144480001315X

Dörnyei, Z. (2001). Motivational strategies in the language classroom. Cambridge University Press.

Fang, F. (Gabriel). (2018). Ideology and identity debate of English in China: Past, present and future. Asian Englishes, 2O(1), 15-26. https://doi.org/10.1080/13488678.2017.1415516

Gardner, R. C. (1975). Second language acquisition: A social psychological approach (No. 332; Research Buletin).

Gardner, R. C. (1985). Social psychology and second language learning: The role of attitudes and motivation (the social psychology of language). Hodder Arnold.

Gardner, R. C. (2004). Attitude/Motivation Test Battery: International AMTB Research Project. The University of Western Ontario. 
Gardner, R. C. (2001). Integrative motivation and second language acquisition. Motivation and second language acquisition, 23, 1-19.

Gardner, R. C. (2012). Integrative motivation and global language (English) acquisition in Poland. Studies in Second Language Learning and Teaching, 2(2), 215-226. https://doi.org/10.14746/ssllt.2012.2.2.5

Gardner, R. C., Lalonde, R. N., \& Moorcroft, R. (1985). Second language learning: Correlational and experimental considerations. Language learning, 35(2), 207-227. https://doi.org/57155

Ghanbarpour, M. (2014). Instrumental and integrative orientations: Predictors of willingness to communicate in the Iranian EFL context. Iranian Journal of Language Teaching Research, 2(2), 87-103.

Glasgow, G. P. (2018). The persistence of native speakerism in Japanese senior high school curriculum reform: Team Teaching in the "English in English" Initiative. in S. A. Houghton \& K. Hashimoto (Ed.), Towards Post-Native-Speakerism (pp. 197-216). Springer Singapore. https://doi.org/10.1007/978-981-10-7162-1_11

Hansen Edwards, J. G. (2016). The politics of language and identity: Attitudes towards Hong Kong English pre and post the Umbrella Movement. Asian Englishes, $18(2)$, 157-164. https:/ /doi.org/10.1080/13488678.2016.1139937

Hashemi, Z., \& Hadavi, M. (2014). Exploring the roles of integrative and instrumental motivation on English language acquisition among Iranian medical and dentistry students. International Journal of Language and Linguistics, 2, 18-23. https://doi.org/10.11648/j.ij11.s.2014020501.13

Hashimoto, K. (2018). "Mother Tongue Speakers" or "Native Speakers"?: Assumptions Surrounding the Teaching of Japanese as a Foreign Language in Japan. in S. A. Houghton \& K. Hashimoto (Ed.), Towards Post-Native-Speakerism (pp. 61-77). Springer Singapore. https://doi.org/10.1007/978-981-10-7162-1_4

Heimlich, E. (2018). Jumping Scale in the World-System with English as a Lingua Franca: Branding, Post-Native-Speakerism, and the Meaning of "a Singapore." in S. A. Houghton \& K. Hashimoto (Ed.), Towards PostNative-Speakerism (pp. 169-193). Springer Singapore. https://doi.org/10.1007/978-981-10-7162-1_10

Jiang, Y. (2014). Identity, motivation and autonomy in language learning. International Journal of Bilingual Education and Bilingualism. https://doi.org/10.1080/13670050.2013.857506

Kitjaroonchai, N, \& Kitjaroonchai, T. (2012). Motivation toward English language learning of Thai students majoring in English at Asia-Pacific International University. Catalyst, 7(1), 21-38.

Kitjaroonchai, Nakhon. (2013). Motivation toward English language learning of students in secondary and high schools in Education Service Area Office 4, Saraburi Province, Thailand. International Journal of Language and Linguistics, 1(1), 22. https://doi.org/10.11648/j.ijl1.20130101.14 
Kunschak, C. (2018). Going Beyond Native-Speakerism: Theory and Practice from an International Perspective. in S. A. Houghton \& K. Hashimoto (Ed.), Towards Post-Native-Speakerism (pp. 149-168). Springer Singapore. https://doi.org/10.1007/978-981-10-7162-1_9

Lamb, M. (2012). A self system perspective on young adolescents' motivation to learn English in urban and rural settings. Language Learning, 62(4), 997-1023. https://doi.org/10.1111/j.1467-9922.2012.00719.x

Liu, M. (2007). Chinese students motivation to learn English at the tertiary level. The Asian EFL Journal, 9(1), 126-146.

Long, C., Ming, Z., \& Chen, L. (2013). The study of student motivation on English learning in Junior middle school-A case study of No.5 middle school in Gejiu. English Language Teaching, 6(9), 136-145. https://doi.org/10.5539/elt.v6n9p136

Masgoret, A. M., \& Gardner, R. C. (2003). Attitudes, motivation, and second language learning: A meta-analysis of studies conducted by Gardner and associates. Language Learning, 53(1), 123-163. https://doi.org/10.1111/1467-9922.00212

Maxwell, J. A. (2013). Qualitative research design: An interactive approach (3rd ed). SAGE Publications.

Muftah, M., \& Rafic-Galea, S. (2013). Language learning motivation among Malaysian pre-university students. English Language Teaching, 6(3), 92103. https://doi.org/10.5539/elt.v6n3p92

Muray, G., Gao, X., \& Lamb, T. (2011). Identity, motivation and autonomy in language learning (D. Singleton, Ed.).

Noels, K. A., Pelletier, L. G., \& Vallerand, R. J. (2003). Why are you learning a second language? Motivational orientations and self-determination theory. [References]. Language Learning, 53(Supp11), 33-64. https://doi.org/10.1111/1467-9922.53223

Noels, K., Clément, R., \& Pelletier, L. (2010). Intrinsic, extrinsic, and integrative orientations of French Canadian learners of English. Canadian Modern Language Review, 57(3), 424-442. https://doi.org/10.3138/cmlr.57.3.424

Ooyoung Pyun, D. (2013). Attitudes toward task-based language learning: A study of college Korean language learners. Foreign Language Annals, 46(1), 108-121. https://doi.org/10.1111/flan.12015

Pennington, M. (2009). Characteristics of middle school learners. Pennington Publishing Housed. https://blog.penningtonpublishing.com/reading/characteristics-ofmiddle-school-learners /

Qu, W. (2011). English, Identity and Critical Literacy. Changing English, 18(3), 297-307. https://doi.org/10.1080/1358684X.2011.602837 
Rahman, S. (2005). Orientations and motivation in English language learning: A study of Bangladeshi students at undergraduate level. Asian EFL Journal, 7(1), 1-26.

Samad, A. A., Etemadzadeh, A., \& Far, H. R. (2012). Motivation and language proficiency: Instrumental and integrative aspects. Procedia - Social and Behavioral Sciences, 66 432-440. https://doi.org/10.1016/j.sbspro.2012.11.287

Sepora, T., Mahadi, T., \& Jafari, S. M. (2012). Motivation, its types, and its impacts in language learning. International Journal of Business and Social Science, 3(24), 230-235.

Ubaidillah, M. F. (2018a). The Pedagogy of English as an international language: Indonesian pre-service teachers' beliefs. The Journal of Asia TEFL, 15(4), https://doi.org/10.18823/asiatefl.2018.15.4.23.1186

1186-1194.

Ubaidillah, M. F. (2018b). Uncovering English teachers' beliefs of English as an international Language. Korea TESOL, 14(2), 139-152.

Wang, F. (2008). Motivation and English achievement: An exploratory and confirmatory factor analysis of a new measure for Chinese students of English learning. North American Journal of Psychology, 10(3), 633-646. https://doi.org/Article

Yano, Y. (2020). ELF Research can liberate the Japanese from NativeSpeakerism. in M. Konakahara \& K. Tsuchiya (Ed.), English as a Lingua Franca in Japan (pp. 313-322). Springer International Publishing. https://doi.org/10.1007/978-3-030-33288-4_15

Yu, B., \& Downing, K. (2012). Determinants of international students' adaptation: Examining effects of integrative motivation, instrumental motivation and second language proficiency. Educational Studies, 38(4), 457-471. https://doi.org/10.1080/03055698.2011.643111 